\title{
MUSCLE STRENGTH, GH AND IGF-1 IN OLDER WOMEN SUBMITTED TO LAND AND AQUATIC RESISTANCE TRAINING
}

\author{
FORÇA MUSCULAR, GH EIGF-1 EM IDOSAS SUBMETIDAS AO TREINAMENTO DE FORÇA \\ NOSOLOENAÁGUA
}

\author{
FUERZA MUSCULAR, GHEIGF-1 EN ADULTAS MAYORES SOMETIDAS AL ENTRENAMIENTO \\ DE FUERZA EN SUELO YAGUA
}

\begin{abstract}
Rodrigo Gomes de Souza Vale $e^{1,2,3}$ (Profissional de Educação Física)

Max Luciano Dias Ferrão' (Profissional de Educação Física)

Rodolfo de Alkmim Moreira

Nunes ${ }^{1,2}$ (Médico)

Jurandir Baptista da Silva² (Profissional de Educação Física)

Rudy José Nodari Júnior ${ }^{4}$ (Profissional de Educação Física)

Estélio Henrique Martin Dantas ${ }^{1}$ (Profissional de Educação Física)

1. Universidade Federal do Estado do Rio de Janeiro (UNIRIO),

Laboratório de Biociências da

Motricidade Humana (LABIMH), Rio de Janeiro, RJ, Brazil.

2. Universidade do Estado do

Rio de Janeiro (UERJ), Programa

de Pós Graduação em Ciências

do Exercício e do Esporte, Rio de

Janeiro, RJ, Brazil.

3. Universidade Estácio de Sá,

Laboratório de Fisiologia do Exercício (LAFIEX), Cabo Frio, RJ, Brazil. 4. Universidade do Oeste de Santa Catarina (UNOESC), Joaçaba, SC, Brazil.
\end{abstract}

\section{Correspondence:}

Rua Figueira de Mello, 415, Condomínio São José d’Aldeia, Bananeiras, Araruama, Rio de Janeiro, RJ, Brazil. 28970-000. rodrigovale@globo.com

\section{ABSTRACT}

Introduction: Aging leads to decline in multiple organ systems associated to hormone alterations and loss of muscle mass and strength. Objective: To evaluate the effects of land and water resistance training on muscle strength, basal serum levels of GH, IGF-1, and IGFBP3 in elderly women. Methods: Subjects were distributed in three groups: land resistance training ( $L R T ; n=10$; age: $66.10 \pm 2.77$ years), water resistance training (WRT; $n=10$; age: $67.10 \pm 3.54$ years) and control (CG; $n=10$; age: 68.80 \pm 5.41 years). Muscle strength was assessed with the 1-RM test in bench press (BP) and leg press (LP) exercises. Serum levels of GH, IGF-1, and IGFBP3 were analyzed by chemiluminescence. Results: Repeated measures ANOVA showed elevated muscle strength in the BP only in $\operatorname{LRT}(\Delta \%=60.2 \% ; \mathrm{p}=0.0001)$ when compared to the $\mathrm{CG}(\Delta \%=46.73 \%, \mathrm{p}=0.0001)$ and WRT $(\Delta \%=32.49 \%, \mathrm{p}=0.004)$. LRT and WRT increased muscle strength in LP ( $\Delta \% L R T=57.14 \% ; p=0.004 ; \Delta \% W R T=42.3 \% ; p=0.033)$. There was an increase in LRT and WRT in the LP when compared to $C G(\Delta \%=45.59 \%, p=0.019 ; \Delta \%=43.97 \%, p=0.026$, respectively). IGF-1 was elevated only in LRT $(\Delta \%=49.72 \%, \mathrm{p}=0.004)$ from pre- to post-test and when compared to WRT $(\Delta \%=56.76 \%, p=0.002)$ and $C G(\Delta \%=74.63 \%, p=0.0001)$. IGFBP3 levels showed that only WRT increased $(\Delta \%=26.79 \%, p=0.044)$ from pre- to post-test. The IGF-1/IGFBP3 ratio demonstrated that LRT reached intragroup elevation ( $\Delta \%=52.66 \%, p=0.002)$ and when compared to WRT ( $\Delta \%=94.11 \%, p=0.0001)$ and CG $(\Delta \%=73.45 \%$, $\mathrm{p}=0.0001)$. There was no significant difference in $\mathrm{GH}$. Conclusion: Land resistance training may provide better anabolic effects in elderly women.

Keywords: motor activity; hormones; aging

\section{RESUMO}

Introdução: O envelhecimento leva ao declínio de múltiplos sistemas de órgãos associado a alterações hormonais e perda de massa e força muscular. Objetivo: Avaliar os efeitos do treinamento de força no meio terrestre e aquático sobre a força muscular e os níveis séricos basais de GH, IGF-1 e IGFBP3 em mulheres idosas. Métodos: Os indivíduos foram distribuidos em três grupos: treinamento de força no meio terrestre (TFT; $n=10$; idade: $66,10 \pm 2,77$ anos), treinamento de força na água (TFA; $n=10$; idade: $67,10 \pm 3,54$ anos) e grupo controle (GC; $n=10$; idade: $68,80 \pm$ 5,41 anos). A força muscular foi avaliada pelo teste de 1-RM nos exercícios supino reto (SR) e leg press (LP). Os níveis séricos de GH, IGF-1 e IGFBP3 foram analisados por quimioluminescência. Resultados: O teste ANOVA com medidas repetidas mostrou aumento da força muscular no SR só no TFT ( $\triangle \%=60,2 \% ; p=0,0001)$ quando comparado ao GC $(\Delta \%=46,73 \%, p=0,0001)$ e TFA ( $\triangle \%=32,49 \%, p=0,004)$. TFT e TFA aumentaram a força muscular no LP ( $\triangle \%$ TFT $=$ $57,14 \% ; p=0,004 ; \Delta \%$ TFA $=42,3 \% ; p=0,033)$. Houve um aumento no TFT e TFA no LP em comparação com o GC ( $\triangle \%$ $=45,59 \%, p=0,019 ; \Delta \%=43,97 \%, p=0,026$, respectivamente). IGF-1 aumentou só no TFT $(\Delta \%=49,72 \%, p=0,004)$ do pré para o pós-teste e quando comparado ao TFA ( $\triangle \%=56,76 \%, p=0,002)$ e ao GC $(\Delta \%=74,63 \%, p=0,0001)$. Os níveis de IGFBP3 mostraram aumento apenas no TFA $(\triangle \%=26,79 \%, p=0,044)$ do pré para o pós-teste. A razão IGF-1/IGFBP3 demonstrou que TFT atingiu elevação intragrupo $(\triangle \%=52,66 \%, p=0,002)$ e quando comparado ao TFA $(\Delta \%=94,11 \%, p=0,0001)$ e CG $(\Delta \%=73,45 \%, p=0,0001)$. Não foram verificadas diferenças significativas no $G H$. Conclusão: O treinamento de força no meio terrestre produziu maior efeito anabólico nas idosas.

Descritores: atividade motora; hormônios; envelhecimento.

\section{RESUMEN}

Introducción: El envejecimiento lleva al declive de múltiples sistemas de órganos, asociado a cambios hormonales y pérdida de masa y fuerza muscular. Objetivo: Evaluar los efectos del entrenamiento de fuerza en el medio terrestre y acuático sobre la fuerza muscular y los niveles séricos basales de GH, IGF-1 e IGFBP3 en mujeres mayores. Métodos: Los individuos fueron distribuidos en tres grupos: entrenamiento de fuerza en medio terrestre (EFT; $n=10$; edad: 66, 10 $\pm 2,77$ años), entrenamiento de fuerza en medio acuático (EFA; $n=10$; edad: $67,10 \pm 3,54$ años) y grupo control (GC, $n=10$; edad =68,80 \pm 5,41 años). La fuerza muscular se evaluó por la prueba de 1-RM en los ejercicios de press de 
banca (PB) y prensa de pierna (PP). Los niveles séricos de GH, IGF-1 e IGFBP3 se analizaron por quimioluminiscencia. Resultados: La prueba ANOVA con medidas repetidas mostró aumento de la fuerza muscular en el PB sólo en el EFS $(\Delta \%=60,2 \% ; p=0,0001)$ en comparación al GC $(\Delta \%=46,73 \%, p=0,0001)$ y EFA $(\Delta \%=32,49 \%, p=0,004)$. EFS y EFA aumentaron la fuerza muscular en la PP ( $\triangle \% E F S=57,14 \% ; p=0,004 ; \triangle \% E F A=42,3 \% ; p=0,033)$. Se observó un aumento en el EFS y EFA en la PP en comparación con el GC $(\triangle \%=45,59 \%, p=0,019 ; \Delta \%=43,97 \%, p=0,026$, respectivamente). IGF-1 aumentó sólo en el EFS ( $\triangle \%=49,72 \% ; p=0,004)$ del pre para el post-testyen comparación con el EFA $(\Delta \%=56,76 \% ; p=0,002)$ y al GC ( $\Delta \%=74,63 \% ; p=0,0001)$. Los niveles de IGFBP3 mostraron aumento sólo en el EFS $(\Delta \%=26,79 \% ; p=0,044)$ del pre para el post-test. La razón IGF-1/IGFBP3 demostró que EFS alcanzó elevación intragrupo $(\Delta \%=52,66 \% ; p=0,002)$ yen comparación al $E F A(\Delta \%=94,11 \%, p=0,0001)$ y GC $(\Delta \%=73,45 \% ; p=0,0001)$. No se observaron diferencias significativas en el GH. Conclusión: El entrenamiento de fuerza en el medio terrestre produjo un mayor efecto anabólico en las mujeres mayores.

Descriptores: actividad motora; hormonas; envejecimiento.

\section{INTRODUCTION}

Aging leads to declines in multiple organic systems associated to hormone alterations ${ }^{1}$. Loss of muscle mass and strength is a important problem during aging ${ }^{2}$. Grow hormone $(\mathrm{GH})$ is the principal regulator of the insulin growth factor 1 (IGF-1) and both are considered important protein anabolic agent for body homeostasis ${ }^{3}$. The IGF-1 is linked primarily to the IGFBP-3 carrier (Insulin-like binding protein-3)4. IGF-1 secretion declines with age as does IGFBP-3 secretion ${ }^{5}$.

These hormonal alterations may be related to loss of muscle mass and strength ${ }^{6}$, making the aged more susceptible to diseases and dependen$\mathrm{cy}^{7}$. However, those engaging in physical training may develop skeletal muscle fiber hypertrophy as a function of increased IGF-1 production ${ }^{8}$ and after mechanical strain in the expression of mechano growth factor (MGF), a member derived of the IGF-12.

Land and water resistance training are recommended to improve the physical conditioning of elderly individuals ${ }^{9}$. The resistance training can improve muscle strength and functional status ${ }^{10}$. Exercising in water has produced strength gains in the elderly when compared to sedentary subjects ${ }^{11}$. The same results are observed in aged practitioners of land resistance training ${ }^{12}$.

However, the variation in IGF-1 and its IGFBP3 carrier may exhibit different responses to physical training depending on the stimulus type and environment used ${ }^{13}$. Some studies show elevated IGF-1 with land resistance training of high intensity ${ }^{14}$, while research by Izquierdo et al. ${ }^{15}$ found no alterations. In the liquid medium, Ay and Yurtkuran ${ }^{16}$ recorded an increase in IGF-1 with the use of aquatic exercises of low intensity, but the study by Vale et al. ${ }^{13}$ did not obtain the same result with aerobic exercises. However it is not very clear about the effects of the resistance training intensity in different environment as land and water on circulating levels of these hormones.

Thus, the type of exercise prescription in the environment appropriate can be important for achieving healthy aging. Accordingly, this study aimed at evaluating the effects of land and water resistance training of high intensity on muscle strength and basal serum levels of GH, IGF-1 and IGFBP3 in elderly women.

\section{MATERIAL AND METHODS}

The sample was drawn of 95 women aged 60 years or older, retired or not, from any socioeconomic class, enrolled in a social project in the city of Araruama, RJ, Brazil. Inclusion criteria were: independent in their activities of daily living (ADL), able to take part in the intervention and study protocols, as determined by medical evaluation and not having engaged in regular physical activities for at least 6 months.

The following exclusion criteria were adopted: subjects who were undergoing any type of hormone replacement therapy and/ or those exhibiting any disease or condition that would contra-indicate a physical exercise program.

After these criteria were applied, 38 women were selected and randomly distributed into three groups, but due to health conditions or lack of interest in participation, eight subjects dropped out from the study, three of each experimental group and two of control group (Figure 1): land resistance training group (LRT), water resistance training group (WRT) and control group (CG). The sample characteristics did not show significant different at baseline (Table 1).

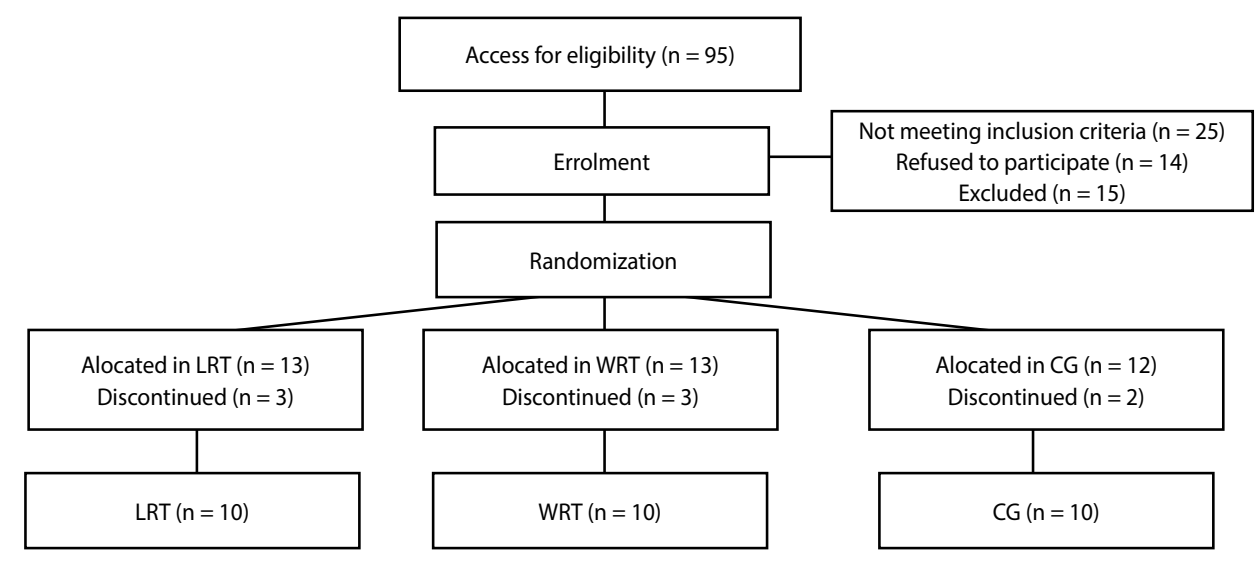

Figure 1. Distribution of the subjects of the sample. 
Table 1. Sample characteristics (mean \pm SD).

\begin{tabular}{c|c|c|c|c}
\hline & LRT & WRT & CG & p-value \\
\hline Age (years) & $66.10 \pm 2.77$ & $67.10 \pm 3.54$ & $68.80 \pm 5.41$ & NS \\
\hline Weight $(\mathrm{kg})$ & $66.14 \pm 13.71$ & $66.66 \pm 6.20$ & $67.19 \pm 7.20$ & NS \\
\hline Height $(\mathrm{m})$ & $1.54 \pm 2.09$ & $1.52 \pm 3.04$ & $1.50 \pm 2.53$ & NS \\
\hline BMl $\left(\mathrm{kg} / \mathrm{m}^{2}\right)$ & $27.50 \pm 3.62$ & $28.70 \pm 2.65$ & $29.70 \pm 2.82$ & NS \\
\hline
\end{tabular}

The study was approved by the institutional ethics committee (protocol number:0017031700008) and subjects gave their written informed consent in accordance with the Guidelines and Norms Regulating Research Involving Human Beings established by the Declaration of Helsinki ${ }^{17}$.

\section{Data collection procedures}

A mechanical balance with stadiometer, accurate to 100 grams and capacity of 150 kilograms (Filizola, Brazil) was used to measure body mass, height and body mass index (BMI), following International Society for the Advancement of Kinanthropometry (ISAK) recommendations ${ }^{18}$.

\section{Analysis of serum IGF-1, IGFBP3 and GH levels}

Blood was collected in the morning until 7:00h to determine basal serum levels of IGF-1, IGFBP3 and the growth hormone $(\mathrm{GH})$ after 12 hours fasting at a clinical analysis laboratory. IGF-1, IGFBP3 and GH were analyzed using the chemiluminescence method - IMMULITE - DPC MED LAB (closed vacuum system). It was calculated the ratio between IGF-1 and IGFBP3. Reference values followed the mean age range of the group (66 to 70 years): IGF-1 - 69 to 200 ng/ml; IGFBP3 - 6.2 to 19.4 $\mathrm{mcg} / \mathrm{dl}$ and $\mathrm{GH}-<3.61 \mathrm{ng} / \mathrm{dl}^{19}$. The same procedures were adopted at the end of the intervention. All the tests were confirmed.

Bench press (BP) and leg press (LP) exercises were used for the one repetition maximum (1-RM) test because they are very used to assessment the lower and upper limb muscle strength in elderly. Participants underwent four familiarization sessions to learn the exercises before performing 1-RM tests. Reliability for the 1-RM test was established by applying this protocol. Nine randomly selected subjects (three from each group) were tested at 72-hour intervals, showing intraclass coefficients of 0.92 and 0.93 for BP and LP, respectively. A paired-samples t-test demonstrated no significant difference $(p<0.05)$ between $1-R M$ tests at the different times.

The LRT group performed land resistance training in two phases: basic (four weeks; $3 \times 15$ repetitions; $50 \%$ of 1-RM) and specific (eight weeks; $3 \times 8-10$ repetitions; $75-85 \%$ of 1-RM). Training occurred three times a week on alternate days with sessions consisting of warm-up, main work out and cool down over a period of 50 minutes. Warm-up involved moving the major joints for 10 minutes. During the main routine, three sets of 8 to 10 repetitions were performed with a rest period of 30 seconds to one minute between sets. The exercise program alternated body segments with the following exercises: bench press (BP), leg press (LP), lat pull-down, leg curls, dumbbell biceps curls, leg extension, triceps curls and abdominal sit ups. During the intervention, load was set in accordance with the OMNI-RES scale of perceived exertion ${ }^{20}$ to between 3 and 5 (light to middle intensity) in the basic phase and between 5 and 8 (strong intensity) in the specific phase. During the cool down period, stretching exercises were performed at submaximal levels. The perceived effort scale for flexibility (PERFLEX) ${ }^{21}$ was used to control stretching exercise intensity that indicated exertion between scores 31 and 60 (LRT $=45.3 \pm 4.2)$.

The WRT group performed water resistance training in a heated pool $\left(27\right.$ to $\left.29^{\circ} \mathrm{C}\right), 1.00$ to $1.40 \mathrm{~m}$ deep, in which subjects had to maintain the waterline at armpit level. The intervention was divided into two phases: basic (four weeks; $3 \times 15$-20 repetitions; with no aquatic accessories) and specific (eight weeks; $3 \times 8$-10 repetitions; with aquatic accessories). Three 50-minute sessions were held per week on alternate days, consisting of warm up, main work out and cool down, Warm up (10 minutes) involved walking exercises, lateral side steps, alternating different arm and leg movements. In the main work out (35 minutes), three sets of 8 to 10 repetitions were performed with a rest period of 30 seconds to one minute between sets, using specific accessories for aquatic exercises: dumbbells, shin weights and gloves. Exercises were carried out alternating body segments, as follows: shoulder horizontal flexion and extension to the waterline, knee flexion and extension, shoulder adduction and abduction in oblique direction, plantar flexion and abdominal crunch. A 5-minute cool down period at the end of each session consisted of stretching exercises at submaximal levels. Training load was controlled by maintaining OMNI-RES scale of perceived exertion between levels 3 and 5 (light to middle intensity) in the first 4 weeks and between 5 and 8 (strong intensity) until the end of the intervention. During the cool down period, stretching exercises were performed at submaximal levels with the perceived effort scale for flexibility (PERFLEX) that indicated exertion between scores 31 and 60 (WRT $=44.9 \pm 6.9$ ).

The average adherence in the 48 sessions was $93 \%$ and no statistically significant differences were detected between LRT and WRT. During the period of intervention, LRT and WRT exercises intensities were similar. Controls were instructed to continue their normal daily activities and agreed not to engage in physical activity during the study period.

\section{Statistical analysis}

Data were analyzed by SPSS 20 for Windows and presented as mean, standard deviation and percentage. Normality and variance homogeneity of data were determined using Shapiro-Wilk and Levene tests, respectively. Repeated measures ANOVA was applied with groups (LRT,WRT and CG) and time (pre- and post-test) for within and between comparisons, followed by the Tukey post-hoc test to identify possible differences. The significance level was set at $p<0.05$ for all tests.

\section{RESULTS}

The repeated measures ANOVA showed interaction between groups and time of the measurements (Wilk's Lambda $=0.589, F=3.283, p<0.001$ ). The power of the experiment presented to IGF-1, IGFBP3, IGF-1/IGFBP3 ratio, $\mathrm{GH}, \mathrm{BP}$ and $\mathrm{LP}$ values of $98 \%, 76 \%, 99 \%, 7 \%, 99 \%$ and $99 \%$, respectively, strengthening the magnitude of the results achieved in the analysis of the study.

Intragroup analysis in Table 2 illustrates that LRT increased maximum muscle strength in BP $(\Delta \% \mathrm{LRT}=60.2 \% ; \mathrm{p}=0.0001)$. The WRT and $\mathrm{CG}$ obtained no significant alterations $(\Delta \% \mathrm{WRT}=4.87 \%, \mathrm{p}=0.994 ; \Delta \% \mathrm{CG}=5.94 \%$, $\mathrm{p}=0.991)$. Intergroup comparisons exhibited significant increases in LRT when compared to the CG $(\Delta \%=46.73 \%, p=0.0001)$ and WRT ( $\Delta \%=32.49 \%, p=0.004)$. Intragroup analysis of LRT and WRT displayed a rise in maximum muscle strength in $L P(\Delta \% L R T=57.14 \% ; p=0.004$; $\Delta \% \mathrm{WRT}=42.3 \% ; \mathrm{p}=0.033)$. The $\mathrm{CG}$ showed no significant alterations ( $\Delta \% C G=7.09 \% ; p=0.997)$. Intergroup comparisons exhibited significant increases for LRT when compared to the $C G(\Delta \%=45.59 \%, p=0.019)$ and for WRT also when compared to the $C G(\Delta \%=43.97 \%, p=0.026)$.

Table 3 illustrates the results of serum IGF-1, IGFBP3, IGF-1/IGFBP3 ratio and $\mathrm{GH}$ values. There was a rise in IGF-1 in LRT $(\Delta \%=49.72 \%, \mathrm{p}=0.004)$ from the pre- to the post-test. The other groups did not exhibit significant differences ( $\Delta \% \mathrm{WRT}=4.04 \%, \mathrm{p}=0.999 ; \Delta \% C G=4.21 \%, \mathrm{p}=0.999)$. Intergroup comparisons demonstrated that LRT also obtained greater values in the post-test when compared to WRT $(\Delta \%=56.76 \%, p=0.002)$ and the CG ( $\Delta \%=74.63 \%, \mathrm{p}=0.0001)$. Only WRT showed significantly higher IGFBP3 levels ( $\Delta \% \mathrm{WRT}=26.79 \%, \mathrm{p}=0.044)$ from the pre- to the post-test. There were no alterations in the other groups $(\Delta \% L R T=-2.28 \%, p=0.999$; 
Table 2. Analysis of muscle strength in the bench press exercise (BP) and leg press $(L P)$ in groups submitted to land resistance training (LRT), water resistance training (WRT) and control group (CG).

\begin{tabular}{c|c|c|c}
\hline Variable & Group & $\begin{array}{c}\text { Pre-test } \\
\text { (Mean } \pm \text { SD) }\end{array}$ & $\begin{array}{c}\text { Post-test } \\
\text { (Mean } \pm \text { SD) }\end{array}$ \\
\hline$B P(\mathrm{~kg})$ & LRT & $19.17 \pm 5.22$ & $31.33 \pm 4.03 * \# \S$ \\
\hline & WRT & $21.85 \pm 3.51$ & $23.38 \pm 4.29$ \\
\hline CG & $20.20 \pm 4.37$ & $21.40 \pm 4.90$ \\
\hline LP $(\mathrm{kg})$ & LRT & $61.67 \pm 7.18$ & $99.17 \pm 14.43 * \S$ \\
\hline & WRT & $68.92 \pm 25.75$ & $95.62 \pm 23.23 * \S$ \\
\hline & CG & $63.50 \pm 22.37$ & $68.00 \pm 28.30$ \\
\hline
\end{tabular}

* $p<0.05$ : different from the pre-test value. \# $p<0.05$ : different from the WRT post-test value. $§ p<0.05$ : differen from the $C G$ post-test value.

Table 3. Serum IGF-1, IGFBP3, IGF-1/IGFBP3 ratio and GH levels in groups submitted to land resistance training (LRT), water resistance training (WRT) and control group (CG).

\begin{tabular}{c|c|c|c}
\hline Variable & Group & $\begin{array}{c}\text { Pre-test } \\
\text { (Mean } \pm \text { SD) }\end{array}$ & $\begin{array}{c}\text { Post-test } \\
\text { (Mean } \pm \text { SD) }\end{array}$ \\
\hline IGF-1 $(\mathrm{ng} / \mathrm{ml})$ & LRT & $98.08 \pm 12.98$ & $146.85 \pm 28.59^{*} \# \S$ \\
\hline & WRT & $90.04 \pm 32.80$ & $93.68 \pm 30.85$ \\
\hline IGFBP3 (mcg/dl) & LG & $80.69 \pm 35.03$ & $84.09 \pm 25.48$ \\
\hline & WRT & $2.67 \pm 0.39$ & $2.61 \pm 0.36$ \\
\hline & CG & $2.59 \pm 0.41$ & $3.28 \pm 0.74 *$ \\
\hline IGF-1/IGFBP3 & LRT & $37.72 \pm 0.64$ & $2.63 \pm 0.41$ \\
\hline & WRT & $34.63 \pm 10.42$ & $29.32 \pm 9.92$ \\
\hline & CG & $30.84 \pm 13.50$ & $32.81 \pm 10.60$ \\
\hline GH $(\mathrm{ng} / \mathrm{dl})$ & LRT & $1.98 \pm 1.34$ & $2.08 \pm 0.99$ \\
\hline & WRT & $1.74 \pm 0.90$ & $1.81 \pm 0.93$ \\
\hline & CG & $1.87 \pm 1.55$ & $1.83 \pm 1.42$ \\
\hline
\end{tabular}

* $p<0.05$ : different from the pre-test value. \# $p<0.05$ : different from the WRT post-test value. $\S p<0.05$ : different from the $C G$ post-test value.

$\Delta \% C G=-3.38 \%, p=0.998)$ or intergroup differences. $L R T$ obtained a significant intragroup increase $(\Delta \% \mathrm{LRT}=52.66 \%, \mathrm{p}=0.002)$ in IGF-1/ IGFBP3 ratio and when compared to WRT $(\Delta \%=94.11 \%, \mathrm{p}=0.0001)$ and the $C G(\Delta \%=73.45 \%, p=0.0001)$ in the post-test. The groups did not show alterations in the $\mathrm{GH}$ levels $(\Delta \% \mathrm{LRT}=5.00 \%, \mathrm{p}=0.999 ; \Delta \% \mathrm{WRT}=4.02 \%$, $\mathrm{p}=0.999 ; \Delta \% C G=-2.19 \%, \mathrm{p}=0.999)$. There were no intergroup differences in the post-test ( $\Delta \%$ LRT vs. WRT $=14.86 \%, p=0.996 ; \Delta \%$ LRT vs. WRT $=$ $13.48 \%, \mathrm{p}=0.997 ; \Delta \%$ WRT vs. $C G=-1.20 \%, \mathrm{p}=0.999)$.

\section{DISCUSSION}

The present study showed that the LRT group improved significantly in BP and LP 1-RM tests, butWRT demonstrated a significant increase only in the LP. The CG showed no changes in muscle strength, IGF-1, IGFBP3 or GH. The LRT group exhibited a significant increase in serum IGF-1 levels from the pre- to the post-test and when compared to the other groups in the post-test. The WRT group showed significant improved in the IGFBP-3. However, an elevated IGF-1/IGFBP3 ratio was recorded for LRT between the pre- and post-test when compared to WRT and the CG.

Tsourlou et al. ${ }^{22}$ observed that 12 elderly individuals aged 60 years or older, who took part in a 24-week aquatic exercise program, showed a significant increase in lower and upper limb strength when compared to the control group. However, this result suggests that an aquatic exercise program may produce gains in upper limb muscle strength if it has a most period of intervention, but one of the two upper limb tests used in their study (lat pull-down) found no intra- or intergroup differences in muscle strength. The same occurred in the WRT in the present study, possibly because of the 12-week duration of intervention, however the LRT showed significant increase in the BP. This can also be explained because LRT obtained more neuromuscular adaptations due the training specificity with the routinely performed exercises over the 12-week study.
Another explanation for such a result in WRT might be owing to the effect of exercise performed in a liquid medium. Pantoja et al. ${ }^{23}$ analyzed creatine kinase (CK) blood levels in a group of young trained subjects after 48 hours of a pectoral muscles training session in a liquid medium (resistance equipment used in water; $3 \times 10-\mathrm{RM}$ ) and another on land (dumbbell bench press; $3 \times 10-R M$ ), with a 5 -week interval between sessions. No differences in CK value were recorded in water-based exercises when compared to initial values, while land-based exercises obtained an increase in CK when compared to initial values and aquatic exercises. The authors concluded that the water environment influenced the absence of significant muscle damage. This suggests that exercises performed in a liquid medium may produce lower strength gains due to less muscle stimulation and mechanical strain or muscle damage. This can influence the production of the MGF and IGF-12. However, this can be considered a limitation of the present study because it did not analyze biochemical markers as CK and MGF.

Colado et al. ${ }^{24}$ compared water resistance and land resistance exercises using tube bands in postmenopausal women for 24 weeks. The exercise intensity was controlled by OMNI-RES scale. The lower limb resistance test (60 s squat test) showed no difference between the two groups. Thus, it may show that the water exercises performed with tube band had similar responses on the muscle strength when compared to the land resistance exercises. This shows that controlling of the training intensity conducted with the scale of perceived exertion was efficient in both intervention groups, using specific accessories for aquatic exercises $^{25}$. This strengthens the results of the present study, whereas it used the same intensity control mechanism and found similar results for the muscle strength of the lower limbs in both experimental groups (LRT and WRT).

Orsatti et al. ${ }^{26}$ found a significant increase in IGF-1 levels and upper and lower limb strength in postmenopausal elderly submitted to land resistance training of 60 to $80 \%$ 1-RM (3 sets of 8-12 rep) for 16 weeks (3 $\mathrm{d}$ /week) when compared to a control group. This was also observed by Vale et al. ${ }^{13}$ in elderly individuals who underwent land resistance training for 12 weeks ( $3 \mathrm{~d} /$ week) at intensity between 75 to 85\% 1-RM (2 sets of 8-10 rep), exhibiting a significant rise in IGF-1 and upper limb muscle strength compared to elderly that engaged in water aerobic training. These findings corroborate the present study, in which the LRT group, with training performed between 75 and $85 \%$ 1-RM for 12 weeks, also obtained significant improvements in serum IGF-1 levels and strength gains. It can be observed that strength exercises at intensities between 60 and $85 \%$ 1-RM for 12 weeks or more are sufficient to provide significant benefits to the elderly in terms of strength and IGF-1.

On the other hand, Izquierdo et al. ${ }^{15}$ observed that exercises undertaken at between 60 and 70\% 1-RM showed no significant changes in serum IGF-1 levels after 11 weeks of training in adults. The same occurred in a study by Igwebuike et al. ${ }^{27}$ comparing variation in IGF-1 in a group of postmenopausal women supplemented with $50 \mathrm{mg} / \mathrm{d}$ of dehydroepiandrosterone (DHEA) who underwent aerobic training (70 to 80\% of maximum heart rate) associated to land resistance training (50 to 60\% 1-RM) with that of another group that used a placebo and performed the same training. After 12 weeks of intervention there was a $29.4 \%$ increase in IGF-1 in the group that used DHEA supplementation while the placebo group obtained a decrease of $8.5 \%$. In the present study, LRT showed significant increase of IGF-1 without using supplementation, but the training intensity was higher and reached similar responses.

The basal serum levels of IGF-1 can influence the muscle strength in elderly. Onder et al. ${ }^{14}$ observed two groups of elderly separated according to IGF-1 levels ( $<65 \mathrm{ng} / \mathrm{ml}$ and $\geq 65 \mathrm{ng} / \mathrm{ml}$ ). The group with higher IGF-1 levels had most upper limb muscle strength as assessed by 
dynamometry. Cappola et al. ${ }^{6}$ performed cross sectional analyses using 617 frail and healthy older women with IGF-I levels drawn within $90 \mathrm{~d}$ of measurement of outcomes. After adjustment for age, there was an association between IGF-I and knee extensor strength $(p<0.004)$. The authors concluded that low IGF-I levels were associated with poor knee extensor muscle strength, slow walking speed, and self-reported difficulty with mobility tasks. So it is possible to suggest that high-intensity exercise as used in the LRT may be sufficient to maintain muscular strength and activities daily living levels in aging due to its ability to increase levels of IGF-1.

Ay and Yurtkuran ${ }^{16}$ evaluated 41 postmenopausal women submitted to controlled aerobic aquatic exercises of the low intensity, based on the Borg scale, for six months. They found a significant increase in IGF-1 when compared to the control group. HoweverVale et al. ${ }^{13}$ observed no significant change in the IGF-1 during the 12-week aerobic aquatic intervention. The same result was not obtained for the WRT group in the present investigation with high-intensity training. This suggests that exercises performed in a liquid medium may require more training time and best controlling of frequency and training effort intensity to raise hormone levels.

The IGFBP-3 carrier analyzed here did not increase significantly with LRT; however, this did not occur in the IGF-1/IGFBP3 ratio. This ratio may expresses free IGF-1, which is more likely to reach muscle cells ${ }^{28}$, possibly explaining the results obtained in the present study. It may also express the strict relationship between IGF-1 and strength gain ${ }^{6}$ induced by the greater contribution of free IGF-1, which can improve lean mass ${ }^{29}$. Duschesk et al. ${ }^{29}$ observed 30 elderly men who used testosterone or placebo for 12 weeks and did not engage in physical activity. The group that used testosterone had an increase in IGF-1, but not in IGFBP-3, showing that a rise in IGF-1 is not always accompanied by an increase in IGFBP3.
Onambélé-Pearson et al. ${ }^{30}$ conducted a land resistance training program for lower limbs in two groups of elderly subjects (80\% 1-RM; 40\% 1-RM), three times a week, associated to other physical activities. They found a significant increase in IGFBP-3 for the group submitted to lower intensity training. The higher intensity group exhibited lower circulating volume of IGFBP-3 compared to the pre-test. This also occurred in the present study, in which the LRT group showed lower values of this hormone in the post-test when compared to the pre-test, whereas the WRT group had an increase in this carrier.

GH is normally evaluated together with IGF-1 to observe possible alterations in individuals submitted to resistance training ${ }^{7,8}$ but the present study recorded no significant modifications in $\mathrm{GH}$. This may have occurred due to GH pulsatility, whose highest secretion peak occurs at night and between 10 and 20 minutes after physical exercise.

\section{CONCLUSION}

In conclusion, the present study demonstrated that exercise stimuli between 75 and 85\% 1-RM in land resistance training promoted significant increases in lower and upper limb muscle strength, IGF-1 levels and IGF-1/IGFBP3 ratio over a 12-week period. However, water resistance training did not provoke a rise in IGF-1 or upper limb muscle strength, but did increase IGFBP3 and lower limb muscle strength. This suggests that land resistance training (75 to 85\% 1-RM) may provide greater anabolic benefits in elderly individuals. Thus, new studies that include other types of water training are recommended, as well as the use of longer intervention periods to confirm the findings of the present study

All authors declare no potential conflict of interest related to this article.

AUTHORS' CONTRIBUTIONS: Each author made significant individual contributions to this manuscript. RGSV (0000-0002-3049-8773)* contributed in writing, review, data analysis and intellectual concept of the manuscript. MLDF $(0000-0002-9571-1651)^{*}$ contributed to the writing of the article and the design of the research project. RAMN $(0000-0001-9707-2649)^{*}$ and RJNJ (0000-0002-8375-657x)* reviewed the manuscript. JBS (0000-0001-6905-4822)* contributed to the preparation of the research project and writing of the manuscript. EHMD (0000-0003-0981-8020)* collaborated with intellectual concept of manuscript and revision. ${ }^{*}$ ORCID (Open Researcher and Contributor ID).

\section{REFERENCES}

1. Aubertin-Leheudre M, Goulet ED, Dionne IJ. Enhanced rate of resting energy expenditure in women using hormone-replacement therapy: preliminary results. J Aging Phys Act. 2008;16(1):53-60.

2. Kandalla PK, Goldspink G, Butler-Browne G, Mouly V. Mechano Growth Factor E peptide (MGF-E), derived from an isoform of IGF-1, activates human muscle progenitor cells and induces an increase in their fusion potential at different ages. Mech Ageing Dev. 2011;132(4):154-62.

3. Frystyk J. Exercise and the growth hormone-insulin-like growth factor axis. Med Sci Sports Exerc. 2010;42(1):58-66

4. Grimberg A, Cohen P. Role of insulin-like growth factors and their binding proteins in growth control and carcinogenesis. J Cell Physiol. 2000;183(1):1-9.

5. Friedrich N, Haring R, Nauck M, Lüdemann J, Rosskopf D, Spilcke-Liss E, et al. Mortality and serum insulin-like growth factor (IGF)-I and IGF binding protein 3 concentrations. J Clin Endocrinol Metab. 2009;94(5):1732-9.

6. Cappola AR, Bandeen-Roche K, Wand GS, Volpato S, Fried LP. Association of IGF-I levels with muscle strength and mobility in older women. J Clin Endocrinol Metab. 2001;86(9):4139-46.

7. Ruiz-Torres A, Soares de Melo Kirzner M. Ageing and longevity are related to growth hormone/insulin-like growth factor-1 secretion. Gerontology. 2002;48(6):401-7.

8. Rubin MR, Kraemer WJ, Maresh CM, Volek JS, Ratamess NA, Vanheest JL, et al. High-affinity growth hormone binding protein and acute heavy resistance exercise. Med Sci Sports Exerc. 2005;37(3):395-403.

9. American College of Sports Medicine. American College of Sports Medicine position stand. Progression models in resistance training for healthy adults. Med Sci Sports Exerc. 2009;41(3):687-708.

10. Fragala MS, Fukuda DH, Stout JR, Townsend JR, Emerson NS, Boone $\mathrm{CH}$, et al. Muscle quality index improves with resistance exercise training in older adults. Exp Gerontol. 2014;53:1-6.

11. Bergamin M, Ermolao A, Tolomio S, Berton L, Sergi G, Zaccaria M. Water-versus land-based exercise in elderly subjects: effects on physical performance and body composition. Clin Interv Aging. 2013;8:1 109-17.

12. Eyigor S, Karapolat H, Durmaz B. Effects of a group-based exercise program on the physical performance, muscle strength and quality of life in older women. Arch Gerontol Geriatr. 2007;45(3):259-71.

13. Vale RG, de Oliveira RD, Pernambuco CS, de Meneses YP, Novaes JS, et al. Effects of muscle strength and aerobic training on basal serum levels of IGF-1 and cortisol in elderly women. Arch Gerontol Geriatr. 2009;49(3):343-7.

14. Onder G, Liperoti R, Russo A, Soldato M, Capoluongo E, Volpato S, et al. Body mass index, free insulin-like growth factor l, and physical function among older adults: results from the ilSIRENTE study. Am J Physiol Endocrinol Metab. 2006;291(4):E829-34

15. Izquierdo M, Ibañez J, González-Badillo JJ, Häkkinen K, Ratamess NA, et al. Differential effects of strength training leading to failure versus not to failure on hormonal responses, strength, and muscle powe gains. J Appl Physiol (1985). 2006;100(5):1647-56.

16. Ay A, Yurtkuran M. Evaluation of hormonal response and ultrasonic changes in the heel bone by aquatic exercise in sedentary postmenopausal women. Am J Phys Med Rehabil. 2003;82(12):942-9.

17. World Medical Association. World Medical Association Declaration of Helsinki. Ethical principles for medical research involving human subjects. Bull World Health Organ. 2001;79(4):373-4.

18. Marfell-Jones M, Olds T, Stewart A, Carter L. International standards for anthropometric assessment. Potchefstroom, South África: ISAK; 2012.

19. Instituto de Patologia Clínica Hermes Pardini (IPCHP). Manual de exames. Belo Horizonte: IPCHP; 2007.

20. Robertson RJ, Goss FL, Rutkowski J, Lenz B, Dixon C, Timmer J, et al. Concurrent validation of the OMNI perceived exertion scale for resistance exercise. Med Sci Sports Exerc. 2003;35(2):333-41.

21. Dantas EHM, Salomão PT, Vale RGS, Achour Júnior A, Simão R, Figueiredo NMA. Scale of perceived exertion in the flexibility (PERFLEX): a dimensionless tool to evaluate the intensity? Fit. Perf. J. 2008;7(5):289-294

22. Tsourlou T, Benik A, Dipla K, Zafeiridis A, Kellis S. The effects of a twenty-four-week aquatic training program on muscular strength performance in healthy elderly women. J Strength Cond Res. 2006;20(4):811-8.

23. Pantoja PD, Alberton CL, Pilla C, Vendrusculo AP, Kruel LF. Effect of resistive exercise on muscle damage in water and on land. J Strength Cond Res. 2009;23(3):1051-4.

24. Colado JC, Triplett NT, Tella V, Saucedo P, Abellán J. Effects of aquatic resistance training on health and fitness in postmenopausal women. Eur J Appl Physiol. 2009;106(1):113-22.

25. Katsura Y, Yoshikawa T, Ueda SY, Usui T, Sotobayashi D, Nakao H, et al. Effects of aquatic exercise training using water-resistance equipment in elderly. Eur J Appl Physiol. 2010;108(5):957-64.

26. Orsatti FL, Nahas EA, Maesta N, Nahas-Neto J, Burini RC. Plasma hormones, muscle mass and strength in resistance-trained postmenopausal women. Maturitas. 2008 Apr;59(4):394-404.

27. Igwebuike A, Irving BA, Bigelow ML, Short KR, McConnell JP, Nair KS. Lack of dehydroepiandrosterone effect on a combined endurance and resistance exercise program in postmenopausal women. J Clin Endocrinol Metab. 2008;93(2):534-8.

28. Stewart CE, Rotwein P. Growth, differentiation, and survival: multiple physiological functions for insulin-like growth factors. Physiol Rev. 1996;76(4):1005-26.

29. Duschek EJ, Gooren LJ, Netelenbos C. Comparison of effects of the rise in serum testosterone by raloxifene and oral testosterone on serum insulin-like growth factor-1 and insulin-like growth factor binding protein-3. Maturitas. 2005;51(3):286-93

30. Onambélé-Pearson GL, Breen L, Stewart CE. Influence of exercise intensity in older persons with unchanged habitual nutritional intake: skeletal muscle and endocrine adaptations. Age (Dordr). 2010 Jun;32(2):139-53. 